\title{
Fresh Graduates face Unemployment
}

Economic growth is not creating a sufficient number of qualified jobs as student numbers continue to rise.

Yu Nanping

\section{(2) OpenEdition}

\section{Journals}

Édition électronique

URL : http://journals.openedition.org/chinaperspectives/786

DOI : $10.4000 /$ chinaperspectives.786

ISSN : 1996-4617

Éditeur

Centre d'étude français sur la Chine contemporaine

\section{Édition imprimée}

Date de publication : 1 février 2004

ISSN : 2070-3449

Référence électronique

Yu Nanping, «Fresh Graduates face Unemployment », China Perspectives [En ligne], 51 I january-

february 2004, mis en ligne le 20 avril 2007, consulté le 28 octobre 2019. URL : http://

journals.openedition.org/chinaperspectives/786 ; DOI : 10.4000/chinaperspectives.786

Ce document a été généré automatiquement le 28 octobre 2019

(C) All rights reserved 


\section{Fresh Graduates face Unemployment}

Economic growth is not creating a sufficient number of qualified jobs as student numbers continue to rise.

\section{Yu Nanping}

\section{NOTE DE L'ÉDITEUR}

Translated from the French original by Peter Brown

1 The difficulties young Chinese university graduates have had in finding a job over the past few months have been making the headlines in the media and causing concern throughout society. Education professionals in China have all had something to say about it. A good number of them, referring to the current phase of social transition in China, have come out in favour of the mass education programme that has been practised in recent years in Chinese universities. Others ${ }^{1}$, have raised doubts about the reliability of the figure of only $70 \%$ as the rate of employment for new graduates, which they consider to be alarmist. In fact, according to the statistics provided by the Ministry of Education itself ${ }^{2}$, out of the 2.12 million graduates in the general higher education sector in 2003, 640,000 had not signed a work contract by the end of their studies $^{3}$.

In these circumstances, it is understandable that in the current labour market in Shanghai, for example, new university graduates are settling for a monthly salary of 1,200 yuan, slightly more than double Shanghai's minimum wage, at the same time as they are having to face significant overheads (superannuation, unemployment insurance, health insurance, etc.) ${ }^{4}$. If we take into account the cost of living in Shanghai (including accommodation, transport and telecommunications), it would appear that the salary of these graduates is barely enough to cover their basic needs ${ }^{5}$. The purpose of this article is to better understand the current unemployment of young 
graduates, beyond any proposals being put forward in the context of higher education reform.

Debate and divergent views about the issue

3 The reform of higher education has brought about the commodification of Chinese universities and a policy of mass recruitment of new students. With whole cohorts of graduating students entering the job market, the unexpected precariousness of job opportunities has given rise to relatively divergent viewpoints within the government's ranks and the world of education. Three competing conceptions are discernible.

4 The first advocates an active search for solutions, by recognising the gravity of the problem. One commentator in the People's Daily (Renmin ribao), for example, has stated that "this is an important matter, and one that affects every sector, as it impinges on the vital interests of more than two million students, as well as on the development of the reform of higher education. It also concerns the strategic measures which have been introduced, aimed at maximising the country's scientific and educational potential and at political stability" ${ }^{6}$. In our view, as we have outlined in a previous article 7 , "the difficulties that young graduates are encountering are the condensed manifestation, in the area of employment, of a short-term imbalance between rapid economic growth and a slower transformation of society. By dint of the nature of this imbalance, both economic and social, economic and social development must be brought into line with each other through a strategy of "putting employment first" if a solution is to be found to the question of unemployment among new graduates.

5 According to a second viewpoint, while the difficulties of young graduates in finding a job are real, there should be no going back on the mass student recruitment drive by universities. In the words of Sun Liping of Qinghua University, "it is pointless denying that the mass recruitment of students has had the consequence of increasing the rate of unemployment among young graduates. However, it is solely the structure of the unemployed population that has been altered by this. By choosing the solution of the least evil, a democratisation of higher education is occurring, as well as a change in the structure of the working population. Thus the difficulties experienced by young graduates must not be a reason for rejecting the mass recruitment of students" 8 .

6 According to Wen Dongmao, the Vice-President of the Education Institute of Peking University, "the situation does not augur well for the future. The problem has to be tackled seriously, yet without overdramatising it" 9. For his part, Yang Yiyong, the Vice-President of the Economic Research Institute at the National Commission for Reform and Development, states that "the initial figures on unemployment depend on quite a number of factors, such that they cannot reflect the real situation in its entirety. Before we can say anything, we have to wait until the end of the year for the second series of data to be released" ${ }^{10}$.

7 According to a third view, the problem is not as serious as the media suggest. It can be fixed through the intervention of the market, as proposed by Cai Fang, of the Bureau of Demographic Studies at the Chinese Academy of Social Sciences: "graduates have to accept selection by the marketplace and to have a reasonable view of themselves, so as to resolve the structural contradictions of employment" ${ }^{11}$. For Li Dongmin, in charge of the Bureau of Sociological Studies in China, "higher education in China has already entered the process of change, going from an elitist system to a democratic one, which will only exacerbate the problem for future graduates looking for work. The state has no need to worry, though. As the notion of employment evolves and the capacity of 
adaptation to the market place is strengthened, new graduates will, in competition with other workers, show the superiority of their skills" ${ }^{12}$.

According to Chen Xian of the University of Shanghai, "if the alarm bells set off by the unemployment of new graduates have been amplified by the market, it is because certain institutions have not been opening up to the job market. The work force cannot, therefore, be entirely determined by market forces." ${ }^{13}$

The three conceptions above have not given place to bitter disputes. But just as these experts see diverse causes of the problem, so they think of different means for resolving the unemployment of new graduates. In this context, we need to look for the reasons that underlie behind the considerable difficulties currently being encountered by young graduates in their search for employment.

The strategy for developing higher education

In order to analyse the difficult situation of new graduates entering the labour market today, we have to come back to the reform of higher education in China, which has taken place over three stages:

1) The first stage was that of "limited development" (1979-91). During this period, the reform of the economic system had not yet reached its full potential. Education was completely left out of the reform process, and continued to function according to the principle of "state centralism". In terms of national planning, and in accordance with its requirements, the education system strictly managed all the "inputs" and "outputs". Although the Resolution of the Central Committee of the Chinese Communist Party on the reform of the education system in 1985 brought about the appearance of more than 400 private tertiary educational institutions (minban or sili) ${ }^{14}$, by attacking the traditional system of management, the overall strategy of reform in China at the time had "the planned market economy" as its underlying principle. It was under the auspices of this principle that the planning of the likely demand for tertiary degrees and diplomas was implemented, as well as a system of setting the numbers entering the system in relation to the capacity of the economy to invest. The development strategy for higher education was underpinned by a deep concern with the question of employment. According to forecasts of the day extrapolating up until 2000, even with an "exceptional rate of development", there would be no more than a maximum of four million tertiary students, making a 5.2\% net rate of student participation ${ }^{15}$. However, from that time on, economically and socially advanced provinces, such as Canton, set up pilot schemes for the mass recruitment of non-scholarship students and those doing training courses.

2) The second stage was that of "regular development" (1992-98). When higher education began its development, its particular feature was the fact that the supply of diplomas in the tertiary sector did not match the demand resulting from growth. Higher education developed on the basis of numbers being controlled and limited, and quality being improved. A report stemming from a study carried out by World Bank experts from 1993 to 1994 had a very profound effect on the transformation of the overall strategy for the development of higher education in China. This report clearly brought out the negative impact on Chinese economic growth of the unduly low proportion of students in the tertiary sector ${ }^{16}$. Moreover, at this time, China had already entered the international market by adopting an export-based economy. In 1998, the Declaration of the World Conference on Higher Education organised by UNESCO in Paris made the Chinese government aware that a rapid increase in the 
enrolment figures in higher education would be a way to respond to the needs of opening up and the requirements of economic and social development.

3) Beginning in 1999, the education system underwent an "accelerated development". A real strategic turning point came at that time, when the higher education sector saw its figures increase in a startling fashion. Not only did student numbers in universities go from 5.04 million in 1998 to 5.94 million in 1999, but tertiary institutions in general increased their intake by $47.4 \%$. Over the same period, experts from the world of education produced a copious literature in which they affirmed that "China can begin the attack on the massification of its higher education sector, as it now has a special feature, that of the plurality of the tertiary system, described by Martin Trow in his theory of massification" ${ }^{17}$.

Many researchers on education, however, failed to take into account either the unprecedented deflation that the Chinese economy was to experience after the terrible floods of 1998, or the slowing down of growth that fell to $7.1 \%$, as a consequence of which experts submitted proposals to state organs to stimulate economic recovery. This involved increasing student numbers and intensifying the commodification of education as a way of stimulating internal consumption. While the deflation, both national and international, of the past few years has not been stemmed in any real way, higher education has seen its numbers constantly grow, under the impact of the strategy of widening the internal demand. Student numbers climbed from 7.23 million in 2000 to 9.31 million in 2001 and 11.46 million in $2002{ }^{18}$.

The development of higher education in China throughout these three stages has been characterised, on the one hand, by the move from a "pure planning model" to a "pure market" one-the tertiary education sector having undergone a gradual change in its direction, doctrine and organisation-and, on the other, by a rapid increase in numbers (20\% a year on average). It was not until 2003 that the capacity of the labour market to accommodate all these new recruits from higher education could be tested for the first time.

The peculiarities and contradictions of the labour market

In order to analyse the unemployment of young graduates, it is important to understand the present state of employment in China. A 1995 study showed that the Chinese workforce available, 755 million people, that is $26.3 \%$ of the world total, was equivalent to 1.64 times the 432 million workers there are in high income countries. However, the total sum of Chinese capital investments represents only $3.4 \%$ of the total world volume. This means that China uses $3.4 \%$ of capital resources to provide more than a quarter of the world's jobs ${ }^{19}$. As China will not enter the phase of zero labour growth until 2020, the impossibility of full employment shows itself to be an inevitable consequence of changing to a market economy and is also intricately bound up with maintaining low labour costs in the country over the long term.

17 Secondly, the transition from a planned to a market economy, as well as the restructuring of particular sectors and the redefining of rights of ownership, are accompanied by the long-term structural unemployment of workers in state-run enterprises. Between 1995 and 2001, employment was reduced by $32.2 \%$ across the whole of this latter sector ( 36.21 million jobs lost). For the collective work units of townships and cantons, the drop was 59\%, which means 18.56 million fewer positions. Overall, there were 54.77 million fewer jobs-double the volume of the entire French workforce ${ }^{20}$. This trend has been further marked these past few years and, although 
new national and foreign investment has taken up a part of the workforce, the number of jobs created is far from meeting the needs of the urban workforce. In 2003, eight million new jobs were created, while the working population grew from 20 to 22 million people. The shortfall is greater still if we take into account the migrant population, over 15 million of whom enter the urban job market each year ${ }^{21}$.

Thirdly, the nature of available jobs is changing. Manual labour is dying out with the change of economic model and technological adjustment. From 1978 to 1996, the value added created by Chinese industry multiplied by a factor of 6.6, which was an annual growth rate approaching $12 \%$. The economy went from a situation of penury to one of chronic surplus, while at the same time as the profit levels in the industrial sector fell rapidly (in the non-monopoly sectors they were below bank interest rates for the same period). This created a significant excess in production capacity, with a rate of equipment use below $40 \%{ }^{22}$ in many spheres of activity. Furthermore, the world technological revolution, bringing about the structural transformation of Chinese industry, saw the export rate of manufactured goods rise from $72 \%$ in 1990 to $88 \%$ in 2000 , while the export rate for hi-tech goods reached $19 \%{ }^{23}$.

Job offers and economic prosperity: no correlation

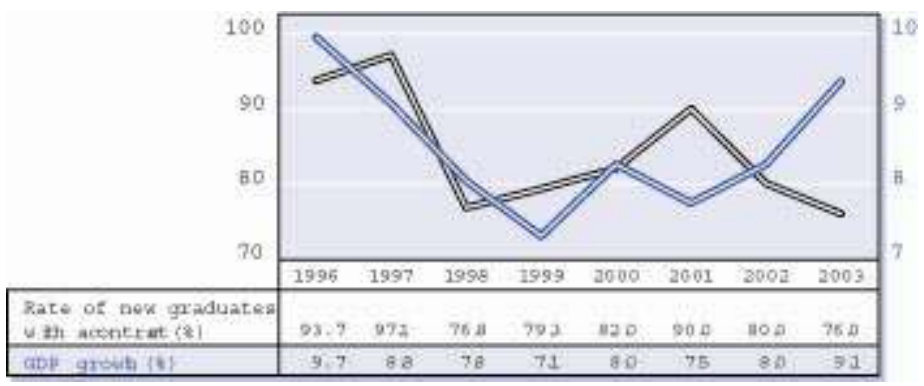

Sources: Zhongguo qingnian bao, August 212003 and China National Bureau of Statistics

It also needs to be said that the distribution of the benefits of Chinese economic growth is increasingly uneven. The Gini ratio has gone from 0.35 in 1988 to about 0.458 today, when the richest $20 \%$ of the population own $48.5 \%$ of all resources ${ }^{24}$. The wealth being created is not going to the majority of the population, which puts a break on the growth of the service sector. Another consequence is that a large part of the workforce has no possibility of moving into the new production sectors, creating a clogging effect in the labour market. In Shanghai, China's most dynamic city, the service sector is growing on average by two points a year, considerably below the pace of economic growth overall. The employment of new graduates depends at the present time, therefore, on the choices being made in terms of employment, which are constrained by historical conditions, and a particular market structure and growth model.

The particular causes of unemployment among new Chinese graduates

There is a distinct lack of correlation between the rate of job offers to new graduates and NDP growth (see Graph 1). In 1999, economic growth was a low $7.1 \%$, while the rate of job offers to new graduates, at $79.3 \%$, exceeded the 1998 figure of $76.8 \%$, for a growth of $7.8 \%$ (to simplify things, we conflate the employment rate and the rate of new graduates under pre-contract). The employment rate for new graduates has most certainly not followed the increase in growth. If the rate of young graduates under a pre-contract in 1998, about $76 \%$, created no panic at all, why then did the $76 \%$ in 2003 
cause so much commotion among the general public and researchers alike? How can this difference be explained?

First of all, we should point out the problematic discrepancy between employment and the strong growth of the Chinese economy that was sustained for nearly five years at a regular average rate of $7.7 \%$. As the harmful effects of SARS were overcome in the first half of 2003, the NDP grew by $8.2 \%$. However, this remarkable economic growth rate did not bring about any effective increase in employment in the major Chinese cities. Shanghai, for example, experienced an unemployment rate of $4.8 \%$ and had 277,800 registered unemployed in April $2003{ }^{25}$. As to Peking, the most recent figures are 5.9\% and 361,000 respectively ${ }^{26}$. In both these cities, unemployment exceeds the $4 \%$ mark set by the state at the beginning of 2003. According to other studies carried out in Chinese cities, the unemployment rate throughout the past few years has steadily been above $8 \%{ }^{27}$, and shows no sign of abating.

It is rather in the structure of Chinese economic growth that we must look for relevant explanations. It would appear that, in spite of an annual growth rate of $30 \%$ for investment in fixed capital and exports that has effectively carried the NDP along with it, the annual growth in household consumption has struggled to stay around the $10 \%$ mark. Not only does the Chinese growth show a structural imbalance (particularly marked by a dramatic take-off in real estate prices that went up in Shanghai by $18.1 \%$ in the first half of $2003{ }^{28}$ ), but the development of the service sector has slowed as a result, at the same time as studies show that the employment-growth elasticity is higher in the service sector (0.57) than in the manufacturing sector (0.34) ${ }^{29}$. In Peking, this ratio underwent a significant drop, with a value of 0.15 during the Eight Five-Year Plan and of 0.09 during the Ninth Five-Year Plan ${ }^{30}$.

In the past, an increase of one point in the NDP would create two million new jobs. Today, it creates only 800,000, with an elasticity somewhere between 0.1 and $0.12{ }^{31}$. Consequently, while investments in fixed capital, real estate, foreign trade and certain industrial sectors such as the automobile industry and metallurgy are becoming the power engines of the economy, jobs in these sectors are not being created at the same pace.

The employment situation in China is very tight overall, with nearly eight million unemployed being registered in the cities and townships in the first half of 2003, and an official unemployment rate of $4.2 \%{ }^{32}$. The rate of recent graduates under pre-contract in 2003 was comparable to that of 1998 and 1999, but in those years students still had a choice of job, whereas at the present time, even with fewer demands, finding a suitable position is a relatively arduous task. The unemployment of which recent Chinese graduates are the victims has nothing to do with traditional structural, frictional unemployment or that linked to the economic climate of the day. Rather, it is related to particular features of Chinese growth, which is not creating enough skilled jobs.

We will now examine the social fallout that is the result of an imbalance in growth leading to a concentration of jobs in particular sectors. The commodification of higher education has transformed the pattern of job allocation for young graduates, which has now become a function of the needs of the labour market. The reform of higher education tuition fees, begun in 1999, has led students embarking on four-year programmes to lay out anything from 50,000 to 80,000 yuan. The fees for a student at a standard university represent $62 \%$ of the average Chinese household budget ${ }^{33}$. The commodification of education assumes, however, that this investment will be 
recovered, that is to say that once they graduate these young people will find a wellpaid job. The difference of more than $40 \%$ between incomes in the east and the west of China is forcing them to seek employment in the cities in the south-east. Today's students are fully engrossed in obtaining their degrees and diplomas, unlike their predecessors of the 1980s who showed more interest in society and the state. This means that merely preaching to them will not see them take off to far-flung parts of the country to set up a business, as did their parents' generation who graduated in the 1950s. Individual investment in higher education and a proper return on such investment must be proportionate to each other.

However, as long as new graduates are obliged to go and seek work in the big coastal cities of the south-east, so as to balance investment in education and real social success-for which their parents deprived themselves-and as long as the social and economic realities constrain students' choices, the gap between the haves and the have-nots will only grow wider and the imbalance in development between the west and the east will contribute to the geographical concentration of jobs for new Chinese graduates. The per capita NDP in the developed zones of the east is today double that of the western provinces, and nearly $60 \%$ of NDP comes from the eastern provinces ${ }^{34}$. The concentration in the east of attractive jobs for young graduates will, over time, come to be a harmful factor, further widening the gulf between east and west. It runs the risk of producing growing regional antagonisms, bringing about the loss of any possibility of social betterment for workers in the west, and undermining the west's development strategy that the government is supporting with large amounts of public money.

The structural weaknesses of economic growth, allied to the extreme imbalance in development between regions, explain the emergence of the growing visibility of new graduate unemployment. An understanding of this problem is the precondition for adopting any workable employment policy.

The social pressure of graduate unemployment

We have to ask ourselves whether this unemployment of new graduates is a specifically Chinese phenomenon. Admittedly, the question of unemployment presents different characteristics in each country, related to the particular social and economic system in place. Nor does there exist any standard tool for measuring the seriousness of a social problem. Nonetheless, studies do show that different social problems emerge, depending on the age group affected by unemployment. Long-term unemployment concerning young people lowers the sense they have of social responsibilities and reduces the quality of human resources, not only of the present but also of the future workforce ${ }^{35}$. Consequently, the employment situation among young people and the pleasure they derive from their work show themselves to be useful indicators for assessing a society's future. Young people contribute to forging the future value system and outlook of a society. These factors also contribute in intangible ways to changing a country's national identity.

29 As far as present-day Chinese students are concerned, public opinion may well carry on constantly criticising their inability to improve their efficiency, their absence of idealism, their lack of a sense of social cohesion and social responsibilities... Yet, the fact remains that objectively speaking the reform and commodification of higher education have led families to invest important sums of money in the education of their children (the fees for a good university in the east of China amount to 10,000 yuan a year, which is equivalent to a whole year's income in a city in the west of the country). 
Students are also subject to incredible psychological pressure. With $30 \%$ of their ranks today unemployed, new graduates may well take a long, hard look at their personal qualities or before choosing their area of specialisation.

The annual growth in the numbers of new graduates, estimated at four million for 2005, and in the rate of young unemployed graduates (with $8 \%$ annual growth, the Chinese NDP may well generate about eight million jobs, but these are mainly ones in manufacturing ${ }^{36}$ requiring low-level qualifications), should logically bring about either a withdrawal from higher education or deviant individual behaviour patterns ${ }^{37}$. This pressure on employment could lead to a destabilisation of society ${ }^{38}$. We can suppose that the students' feeling of social failure may go as far as to find expression in violent protests that could be taken further by other, less educated, sections of society. Moreover, it is important to bear in mind that the social structure of today's China has nothing to do with that of 1989. If there was student agitation back then, it was because different social factions? /groups?, seeing their situation becoming increasingly precarious, had joined forces to shake the power of the authorities, resulting in unforeseeable consequences.

Solutions for resolving the problem

Several solutions are being considered to resolve the problem of the unemployment of young graduates. Some call for a policy of non-intervention based on the natural effects of economic growth. According to Cai Fang, in charge of the Bureau of Demographic Studies in the Chinese Academy of Sciences, "the government should gradually abandon policies aimed specifically at promoting the employment of new graduates, and encourage them to create their own enterprise and accept the realities of the situation" ${ }^{39}$. Chen Xian, a professor at the University of Shanghai, feels that talk about difficulties in finding work for young graduates is exaggerated: "these difficulties are due to the fact that the volume of available jobs in institutions such as those of higher education, government bodies or organs of scientific research has, like recruitment methods, slowed down the process of commodifying the workforce. (...). As to the symptoms affecting the job market, in other words the difficulties in finding a job for new graduates, they have been exaggerated. What is needed, therefore, is a thoroughgoing reform of these institutions" ${ }^{40}$.

First, let us consider the proposal for enterprise creation. At the height of the "neteconomy" in 2000, "the creation of enterprises by young graduates" was the concept most in vogue with public opinion and on the campuses. However, as the economy weakened and fewer investment risks were taken, hardly any cases of successful enterprise creation could be found among those that new graduates had begun to set up (the successful cases were in large part the result of graduates coming back to China after studying abroad). When we know that in China today a large proportion of private capital cruelly lacks opportunities for investment, it could well be that the supposed enterprise creations by young graduates are the wild imaginings of scholars, and will remain in official discourse for a certain time only. In reality, there is very little creation of enterprises by young graduates today and, for want of capital, the trend is clearly towards the creation of small individual businesses (newspaper stands, small bookshops, record shops).

33 Let us now turn to look at the second proposal, namely the commodification of the workforce within public institutions. Even without considering the measures taken in recent years to rejuvenate and improve the training of the Party's cadres and those in 
executive positions in public bodies in the large cities, the level of studies attained is already higher overall than that of a four-year university programme, in accordance with requirements regarding the status of functionaries/civil servants/government workers?. In plain language, thanks to later-year courses ${ }^{41}$, many functionaries/civil servants/government workers? in positions of responsibility have, over the past few years, obtained qualifications that make them more attractive than those with university degrees. While the de facto retirement age in firms has been brought forward to 57 for men and 50 for women, if we suppose that the 40 to 50 year-olds who currently have jobs and who are competent workers with a long professional experience, might also be retrenched to make way for new graduates, it would then be these young retirees who would exert pressure on employment and society alike. Even without thinking about its financial cost, where would such an employment policy by "cyclical substitution" lead if it brought forward the retirement age-to 40 years of age, or even earlier?

It appears plainly to us that encouraging new graduates to set up enterprises is aimed at hedging the problem of unemployment. If it were so easy to set up an enterprise, then the Chinese banks would not be holding thousands of billions of yuan in deposits, without those with the savings being able to benefit from even a $1 \%$ return. The use of substitution labour in public institutions can itself play only a palliative role of support, without being the solution to the problem.

As long as it is impossible to establish a balance between "supply" and "demand", and while market mechanisms are inadequate, the first thing to do is to recognise the singularity and the gravity of the problem. Next, the objectives specific to economic development need to be brought into line with those of social progress, under the banner of the strategic choice of an "employment first" approach. Such a choice implies an important rejigging of objectives, but also a revision of what is understood by economic growth. For their part, local governments have to go through a radical transformation and stop pursuing objectives that are defined solely in terms of competitiveness and entrepreneurship. If job creation and resolving the problem of unemployment become the fundamental long-term objectives, unemployment benefit schemes and casual unemployment relief schemes must be set up that specifically target students (based on the minimum salary in Shanghai, seven billion yuan in unemployment benefits will have to be spent each year for the million new unemployed graduates produced nationally).

Sociological studies show that the threat of unemployment hanging over society does not only consist in deviant individual behaviour patterns. By undermining the selfesteem of individuals and the community as a whole, it also serves to encourage the appearance of anti-social movements. Conceptual approaches to the question in China remain clearly superficial. A good many commentators fail to take into account the means of subsistence of new graduates, yet moral lessons are being handed out to them in abundance. The discourse on the creation of enterprises by young graduates is no more than logorrhoea, although by the same token we should be careful not to trivialise this problem that can potentially produce social conflict. A country's future is its youth, which is the most qualified section of its population. If our society demands of today's new graduates that they marshal their forces to create the future, it is incumbent upon the government for its part to guarantee them the "right to work" or the basic one of being able to be "in line for a job", in the absence of which it is highly 
likely that, following Hemingway's "lost generation" and Ginsberg's "beat generation", the young Chinese graduates will become a "ruined generation". In this respect, we should bear in mind the warning given by Friedrich Hayek: “(...) there exists another serious problem. The number of intellectuals has already exceeded what we are capable of employing gainfully. For the sake of political stability, there is almost nothing that is as dangerous as an 'intellectual proletarian' without future prospects" ${ }^{42}$.

\section{NOTES}

1. Chen Xian, "Yige bei fangda de xinhao" ("An exaggerated interpretation of a sign"), Wenhui bao, Shanghai, July 24th 2003.

2. www.moe.edu.cn, www.edu.cn

3. There is a discrepancy between the statistics published by educational institutions and the real employment situation, which is in part related to the fact that the figures released by the educational institutions on the employment of new graduates take the pre-contracts signed between employers and students as criteria for a job offer. www.chinanews.com.cn

4. Xinwen chenbao (The Morning Herald), June 26th 2003.

5. "Daxue biye sheng shengcun zhuangtai diaocha" "'Study of the living conditions of new graduates", in Shehui diaocha baogao (Report of the sociological study), Sociology Department, Teacher Training University of Eastern China, 2000 graduation class.

6. Renmin ribao (The People's Daily), June 6th 2003.

7. Yu Nanping, "Jiuye wenti hai xu jingji shehui liangshou zhua" ("The problem of unemployment must be tackled both economically and socially"), Jiefang ribao (Le Liberation Daily), August 8th 2003.

8. Sun Liping, "Zhongguo shehui: zai kuozhao yu shiye zhijian" ("Chinese society caught between increased recruitment and unemployment"), Jingji guancha bao (The Economic Observer), July 14th 2003.

9. Zhongguo xinwen zhoukan (China News), No. 139, July 14th 2003, pp. 18-26.

10. Ibid.

11. Ibid.

12. Ibid.

13. Cf. note 1 .

14. Zheng Xiaochun, "Zhongguo gaodeng jiaoyu tizhi gaige de huigu yu zhanwang” ("A Look Back on the Reform of Higher Education and Future Prospects"), in Liaoning gaodeng jiaoyu yanjiu (Research on Higher Education in Liaoning Province), 1998 (1).

15. Zhou Beilong, Mianxiang ershiyi shiji de gaodeng jiaoyu (Higher Education Comes Face to Face with the $20^{\text {th }}$ Century), Beijing gaodeng jiaoyu chubanshe, 1990, pp. 41-198.

16. World Bank, preface by Zhongguo gaodeng jiaoyu gaige (The Reform of Higher Education in China), Zhongguo caizheng jingji chubanshe, Peking, 1998.

17. Pan Maoyuan, "Shilun cong jingying dao dazhong gaodeng jiaoyu de guodu jieduan", ("Essay on the Transitional Phase of Higher Education between Elitism and 
Massification"), Liaoning gaodeng jiaoyu yanjiu (Research on Higher Education in Liaoning Province), 2001 (2).

18. Department of Planning and Development of the Chinese Ministry of Education, Zhongguo jiaoyu tongji baogao (Statistical Report on Education in China), Peking, February 2003.

19. According to the World Bank, Indicators of World Development, 1997.

20. According to the World Bank, Indicators of World Development, 2001, p. 48.

21. Zhao Xiao, "Chuyu linjiedian de Zhongguo shiye wenti" ("The Problem of Unemployment in China at a Critical Point"), Zhongguo jingji kuaixun zhoukan (Economic Bulletin of China), August 1st 2001.

22. Chinese National Bureau of Statistics, www.stats.gov.cn

23. UNO (UNPD) Plan on Resource Exploitation, 2002 nian renlei fazhan baogao (2002 Report on Human Development), Zhongguo caizheng jingji chubanshe.

24. Foundation for Research on Chinese Economic Reform, Zhongguo caifu baogao (Report on China's resources), Shanghai yuandong chubanshe, pp. 182-185.

25. Zhonghua gongshang shibao (The China Times of Industry and Commerce), April 4th 2003. 26. "Beijing shiyelü yi laxiang hongse jingbao" ("The alarm has been sounded for the unemployment rate in Peking"), communiqué from Zhongxinshe, Peking, July 23rd 2003.

27. Hu Angang, Yingxiang juece de guoqing baogao (Report on the Situation of the Country and its Influence on Political Decisions), Qinghua daxue chubanshe, pp. 129-87.

28. Shenzhen shangbao (Shenzhen Commerce Newspaper), July 20th 2003.

29. Zhu Xiaoqing, "Guanyu kuoda jiuye de yidian sikao" ("Some thoughts on the rise in employment"), Guangming ribao (Clarity), July 24th 2003.

30. www.bjstsas.gov.cn

31. See Jingji cankao bao, March 20th 2002 and January 8th 2003.

32. Zhongguo qingnian bao, July 30th 2003.

33. According to the Chinese National Bureau of Statistics, Zhongguo ge diqu chengzhen jumin jiating shouzhi jiben qingkuang (Situation of Households in Cities and Townships in all Regions of China), August 2003.

34. Bureau of Political Studies of the Municipality of Peking, Jingji xingshi fenxi baogao (Report analysing the overall economic situation), An Bang, study published in Meiri jingji (The Economy Day-to-day), 2002.

35. Stiglitz Joseph E, Economics, Norton Inc., 1993.

36. Chinese National Bureau of Statistics.

37. The Zhou Yichao case could serve as a model. See "Daxue biyesheng heyi dongshaji" (“Why do Young Graduates Kill?"), Nanfang zhoumo, April 21st 2003.

38. For similar concepts, see K. Merton, Shehui yanjiu yu shehui zhengce (Research into Sociology and Political Science), Sanlian chubanshe, 2001, pp. 77-97.

39. Cf. note 9.

40. Cf. note 1 .

41. Wenhui bao, Shanghai, August 23rd 2003

42. Ha Yeke (Hayek), Ziyou zhixu yuanli, $2^{\text {nd }}$ volume, translation by Zheng Zhenglai, Sanlian chubanshe, Peking, 1997. 